\title{
Hydro-geomorphologic GIS database in Northern Portugal, between 1865 and 2010: Temporal and spatial analysis
}

\author{
Monica Santos ${ }^{\mathrm{a}, \mathrm{b}, *}$, Carlos Bateira $^{\mathrm{a}}$, Laura Soares ${ }^{\mathrm{a}}$, Carlos Hermenegildo ${ }^{\mathrm{a}}$ \\ a Dynat, CEGOT, University of Oporto, Oporto, Portugal \\ ${ }^{\mathrm{b}}$ Riskam, IGOT, CEG, University of Lisbon, Lisboa, Portugal
}

\section{A R T I C L E I N F O}

\section{Article history:}

Received 4 June 2014

Received in revised form

12 August 2014

Accepted 13 August 2014

Available online 23 August 2014

\section{Keywords:}

Disaster project

GIS database

Floods

Landslides

Northern Portugal

\begin{abstract}
A B S T R A C T
Floods and landslides are the natural hazards that most affect Northern Portugal. This paper presents the DISASTER database results for Northern Portugal, containing occurrences of floods and landslides between 1865 and 2010. The research carried out was based on press articles published in national and regional newspapers, but focusing exclusively the occurrences that caused personal damage, including deaths, injured, missing, evacuees and displaced people, regardless of the number of people affected and the economic value of damages. A total of 613 occurrences were recorded, which $18 \%$ are landslides and $82 \%$ are floods. These occurrences were responsible for 198 deaths, 58 injured, 34 disappeared, 1804 evacuated and 15,918 displaced. The trend analysis shows an increase of 0.17 occurrences/decade. The obtained results show the occurrences concentration in the more urbanized areas and along larger rivers.
\end{abstract}

(c) 2014 Elsevier Ltd. All rights reserved.

\section{Introduction}

Natural hazards, such as floods and landslides, continue to cause considerable damage to the human life, material and functional damages every year. According to the International Strategy for Disaster Reduction [2], in 2012, the ten world's most damaging natural disasters in terms of loss of human life caused 4098 deaths, stressing that the prime responsibility lies in floods and storms, followed by extreme temperatures, earthquakes, landslides and forest fires. Regarding spatial distribution, the same source reports that between 2002 and 2011, the highest percentage of deaths associated with natural disasters occurred in Asia (62.62\%), America (23.19\%), Africa (1,23\%), Oceania $(0,14 \%)$ and Europe (12.82\%), with particular focus on the Elba and Danube floods in August 2002, resulting in 38 deaths [3], and the flash floods that took place on 10

\footnotetext{
* Corresponding author.

E-mail address: monica.s.m.santos@gmail.com (M. Santos).
}

February, 2010 in Madeira, causing 45 deaths [4] and economic damages that amounted to more than 1,350,000 USD [5]. In the Iberian Peninsula, floods and storms are also the main hazards in terms of both the personal damages and the economic losses [6]. However, there are also highly destructive landslides, referring, for instance, to the debris flow which occurred on 7 December, 2000 in Arcos de Valdevez (Northern Portugal), leading to the loss of 4 lives, the destruction of three houses and partially affecting two others, further to having devastated several farming fields [7,8]. Since historical data is the groundwork for natural hazard and risk assessment for understanding the dynamic of the processes, helping to define solutions to mitigate them [9], the compilation of an inventory of occurrences is the primary approach in any research on this field [10]. According Guzzetti and Tonelli [11], historical information on past events is very important in landslide and flood hazards assessment and defining of mitigation strategies.

At a global level, we can highlight the EM-DAT database (http://www.emdat.be), of the Centre for Research on 
the Epidemiology of Disasters (CRED) - Leuven University (l'Université Catholique de Louvain) in Belgium. This database is compiled from several sources and includes data on natural and technological disasters occurred in the world, with ten or more people reported killed or one hundred or more people reported affected since 1900. For the disaster to be registered in de EM-DAT database, at least one of the following criteria must be fulfilled: (1) 10 or more people reported dead; (2) 100 or more people reported affected; (3) declaration of state of emergency; or (4) call for international assistance. For Portugal are registered only 33 disasters during the period 19002000 [12]. The EM-DAT database contained only 13 disasters of hydro-geomorphologic origin for the same period (39\% of total natural disasters). In addition the EM-DAT, does not report any natural disaster in Portugal for the period 1900-1967. At this global level we may also refer to databases such as NatCat (Münich Reinsurance Company), Sigma (Swiss Reinsurance Company) and Disaster Inventory System DesInventar [13]. Several countries also benefit from national databases, such as Great Britain [14], Switzerland [3], Italy [11], Australia [15], the United States of America [16] and Canada [17]. Regarding regional databases, we highlight the one of the Azores, Portugal [18], Catalonia in Spain [6,19], Calabria and Salento in Italy [20,21] and Ardèche River in France [22]. In Portugal similar databases until now did not exist. The purpose of the DISASTER project - natural disasters of hydro-geomorphological origin in Portugal: GIS database to support decisions on spatial planning and emergency planning - is to fill the gap on hydro-geomorphologic disasters with damaging consequences, in mainland Portugal. Hydrogeomorphologic disasters are natural processes of hydrologic nature (river floods, flash floods) or geomorphologic nature (various types of landslides) that generate adverse consequences to population. The main objective is to build, explore and disseminate a geographical database (GDB) on floods or landslides disasters registered, between 1865 and 2010. The spatial and temporal analysis, by these events will enable more accurate spatial management and the development of measures suited to the emergency planning.

This study presents the results of the DISASTER DB in the Northern Portugal, analysing the distribution and temporal trend of hydro-geomorphological occurrences, as well as the most affected areas.

\section{Material and methods}

\subsection{Study area}

The northern region of Portugal, covering an area of $21,278 \mathrm{sq} \mathrm{km}$, has strong spatial contrasts in terms of mean annual rainfall, ranging from $500 \mathrm{~mm}$ in the upper Douro to $3500 \mathrm{~mm}$ in the Peneda-Gerês mountain belt (Fig. 1).

The climate in the northwest region is mainly influenced by the proximity to the Atlantic Ocean, while the low-elevation inner areas (northeast), marked by continentality, typifying the Mediterranean climate [23]. These contrasts between the Northwest and the Northeast of the country are due to the relief, since the geographic orientation of the main upland, parallel to the coastline, forms a barrier to the incoming humid winds from the Atlantic [24]. Thus, the Peneda, Amarela and Gerês mountains record the heaviest values of rainfall in Western Europe [25], while the Northeast, including the upper section of the Douro Demarcated Region and the valleys of some of its tributaries, is one of the driest regions in the country.

\subsection{GIS database: inventory and data}

The first step before the data collection was the definition of the criteria for inclusion of occurrences in the database. Therefore, the criteria of DISASTER database are:

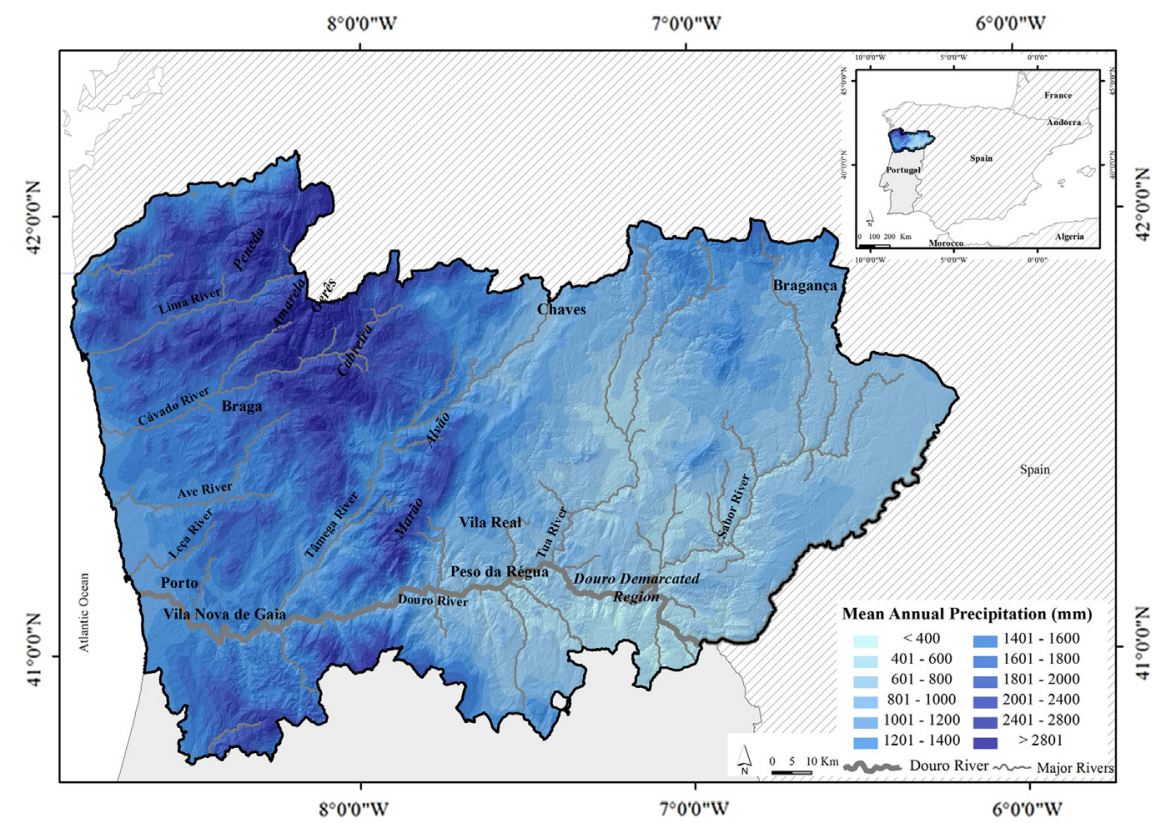

Fig. 1. Location of Northern Portugal, mean annual precipitation (1931-1960) in study area (adapted from [1]). 
any occurrence of floods or landslides that resulting in deaths, injured, missing, evacuated or displaced people, regardless of the number of people affected and the economic value of damages. Since the data source is the newspapers, it is assumed that events that meet the above conditions are important enough to be reported in the regional and national newspapers. A disastrous occurrence is a unique hydro-geomorphological occurrence, which following the DISASTER project database criteria, and is related to a specific period of time and a unique space location. Five daily newspapers and ten weekly newspapers were systematically consulted (Table 1 ), by three research teams belonging to the Oporto, Coimbra and Lisbon Universities.

The next task was related to reading and interpretation of the news, whose majority were in analogical support (paper or microfilm). The news reporting hydro-geomorphological occurrences was scanned and converted into digital support (.PDF) (Fig. 2). All hydro-geomorphological occurrences were validated using the newspaper main report and crosschecking different news sources (national, regional and local newspapers). In total, we analysed 145,344 periodicals, corresponding to a surveyed period of 146 years (1865-2010) [26].

For each hydro-geomorphologic occurrence, we collected the following information: type of occurrence (flood or landslide), sub-type (i.e., river floods, flash flood, debris flow, translational slide; rotational slide; earth fall; rock fall; complex slope movement), date (year, month, day and hour), location (municipality, parish and coordinates of the $\mathrm{x}$ and $\mathrm{y}$ points according to the PT-TM06/ETRS89 projection coordinate system), triggering factor and information source (name, source type and reliability of the news), source, date of source, page number, number of deaths, injured, displaced, evacuees or missing, type of damages in buildings (superficial, structural or functional), number of affected buildings, type of damage in networks (superficial, structural or functional), extent of interruptions in road and railroad circulation, entities involved, material losses and triggering factor. As this DB is developed within a GIS (Geographic Information System), each occurrence is coded and georeferenced using a point shapefile. The newspapers are not always accurate as to the time and location of the occurrence, making it difficult to georeference and then analyse the events. The precision of location was classified into five classes depending on the quality of the description in the news: (1) location with exact coordinates (precision associated with scale 1:1000); (2) location based on local toponymy (precision associated with scale 1:10,000); (3) location based on local geomorphology (precision associated with scale 1:25,000 scale); (4) location in the parish centroid; and (v) location in the municipality centroid. The classes 4 and 5 were used only when the news did not provide any detailed geographic information [26] (Fig. 2). Note also that sometimes the news does not mention the number of people affected, a problem also found by Guzzetti et al. [27] and Quaresma [28]. This holds true in particular with regard to references on evacuees and displaced people, often using the words "many" or "several", or simply mentioning the number of families. In the latter case, we estimated the average size of families based on information provided by the National Statistical Institute (INE) through census data; therefore, in some cases, the results obtained are rough numbers.

\subsection{Temporal distribution}

In Portugal, nationwide information on population is available from 1864, through censuses carried out every 10 years by the Instituto Nacional de Estatística. It is possible to estimate the mortality rate for floods and landslides, combining this information with the annual number of flood and landslide deaths, per unit time [27]. In the study of natural or technological hazards, the mortality rate is expressed by the number of deaths in a population, per 100,000 people in a period of one year [29]. The mortality rate has a limitation, since it depend on the size of the population with which they are associated [27].

In the analysis of the temporal distribution of occurrences, the values of occurrences have been classified through the Jenks natural breaks classification method [30] designed to determine the best arrangement of values into different classes [31]. This method, which is one of the most popular classification methods in cartography [32], arranges values into classes based on natural groupings

Table 1

Newspapers consulted in the disaster project.

\begin{tabular}{|c|c|c|}
\hline Newspaper & Period of publication & Category \\
\hline Diário de Notícias & 1865-2010 & Daily \\
\hline Jornal de Notícias & 1888-2010 & Daily \\
\hline Diário de Coimbra & $1931-2010$ & Daily \\
\hline Correio do Minho & 1955-1959 & Daily \\
\hline Comércio do Minho & 1904-1910 & Daily \\
\hline Notícias de Chaves & 1950-2010 & Weekly \\
\hline Correio de Mirandela & 1907-1937 & Weekly \\
\hline Mensageiro de Bragança & 1940-2010 & Weekly \\
\hline Notícias do Douro & 1934-2007 & Weekly \\
\hline Soberania do Povo & 1936-2010 & Weekly \\
\hline Região de Leiria & 1935-2010 & Weekly \\
\hline Jornal do Fundão & 1946-2010 & Weekly \\
\hline Reconquista & 1950-2000 & Weekly \\
\hline Diário do Alentejo & 1933-2002 & Daily until 1982 and then weekly \\
\hline O Algarve: o semanário independente & 1908-2001 & Weekly \\
\hline
\end{tabular}




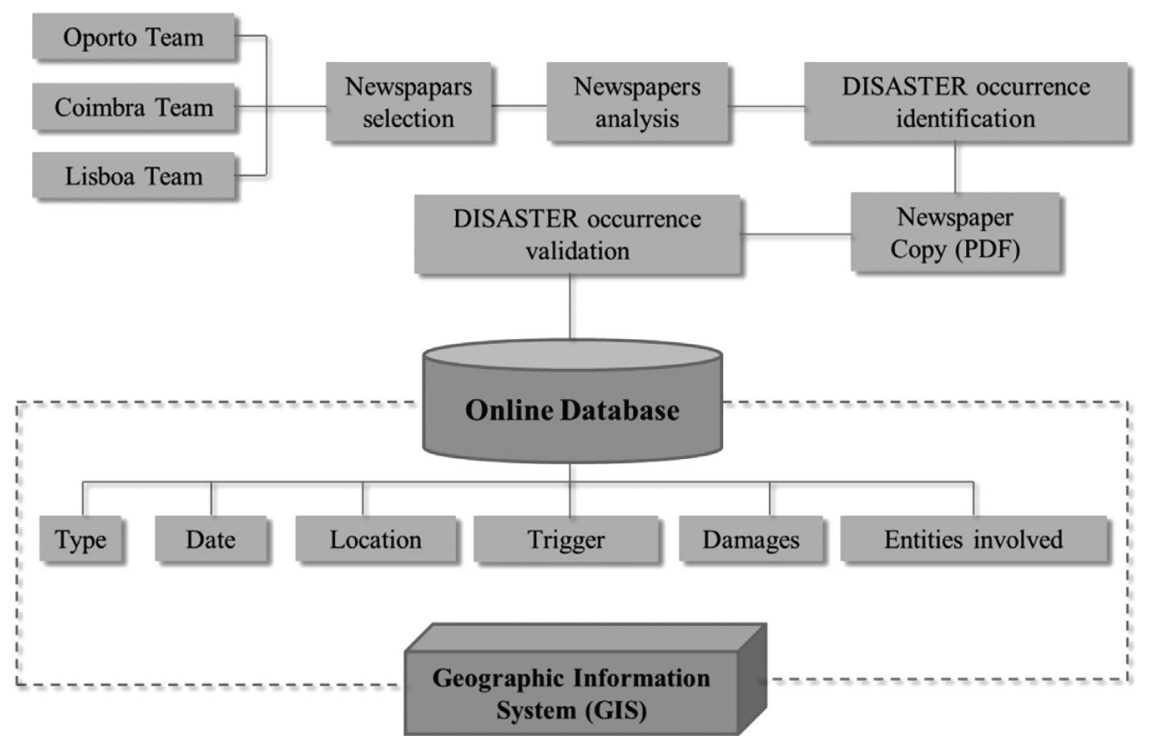

Fig. 2. Methodological scheme for collecting and storing data on the DISASTER database.

inherent in the data, while maximizing differences between classes $[30,33]$.

In the northern region, the only weather station with centennial data is located near the city of Oporto. This station presents data from 1908 to 2005. In this work, we calculated the mean annual precipitation (MAP), the number of rainy day in the year (RD) and the rainy-day standard $(\mathrm{RDN}=\mathrm{MAP} / \mathrm{RD})$.

\subsection{Trend}

The Mann-Kendall [34,35] non-parametric test, was applied to detect long term trends in the occurrences, MAP, RD and RDN. In this test, in the null hypothesis HO, the sequence of values occurs independently and the probability distribution must always remain the same (simple random number). In the alternative hypotheses $\mathrm{H} 1$, the data are distributed according to an increasing or decreasing trend $[24,36]$. The test statistic $t$ is given by:

$t=\sum_{i=1}^{n-1} \sum_{j=i+1}^{n} \operatorname{sgn}\left(X_{j}-X_{i}\right)$

where $\operatorname{sgn}(X)$ is the sign function that presents values equal to $-1,0$ or 1 depending on whether the argument is, negative, zero or positive, respectively. The variance of $t$ under the null hypothesis is given by:

$\operatorname{var}(t)=\frac{n(n-1)(2 n+5)}{18}$

The exact distribution of $t$ can be calculated and, for $n \geq 10$, it approaches a normal distribution, especially if the correction $t^{\prime}=t-\operatorname{sgn}(t)$ is applied. If one considers the normalized variable:

$z=\frac{t}{\sqrt{\operatorname{var}(t)}}$

$z$ is normally distributed with a mean of 0 and a variance of 1 [36] and evaluates a statistically significant trend. A
Table 2

Total number of occurrences and damages per type of hydro-geomorphologic disaster.

\begin{tabular}{lrcrc}
\hline & Floods & Landslides & Total & Total/year \\
\hline Occurrences & 499 & 114 & 613 & 4.2 \\
Dead & 198 & 129 & 327 & 2.3 \\
Injured & 58 & 191 & 249 & 1.7 \\
Disappeared & 34 & 4 & 38 & 0.3 \\
Displaced & 15,918 & 587 & 16,505 & 113.8 \\
Evacuated & 1804 & 155 & 1959 & 13.5 \\
\hline
\end{tabular}

positive value of $z$ shows an upward trend and a negative value of $z$ indicates a downward trend. For estimate the magnitude of the trends, we used the algorithm that corresponds to an extension of the original test put forward by Theil [37] and Sen [38]. Sen's slope is related to the slope of the trend found in the Mann-Kendall test. It is obtained through:

$B=\operatorname{median} \frac{X_{i}-X_{j}}{t_{i}-t_{j}}$

where $X_{i}$ and $X_{j}$ are data values at times $t_{i}$ and $t_{j}(i>j)$, respectively. The test was evaluated for a level of significance of $5 \%$.

\section{Results}

Between 1865 and 2010, there were 613 hydrogeomorphological occurrences in the northern region, 499 of which were floods and 114 landslides (Table 2).

Therefore, of the total number of records in the GDB, floods are assumed to be the prevailing process corresponding to $82 \%$ of the occurrences, among which the river floods (66\%) assume particular emphasis, followed by flash floods (16\%) and urban floodings (18\%) (Fig. 3). Regarding the landslides, in much smaller numbers (18\% of the total occurrences), 39\% correspond to earth falls, 31\% 
A

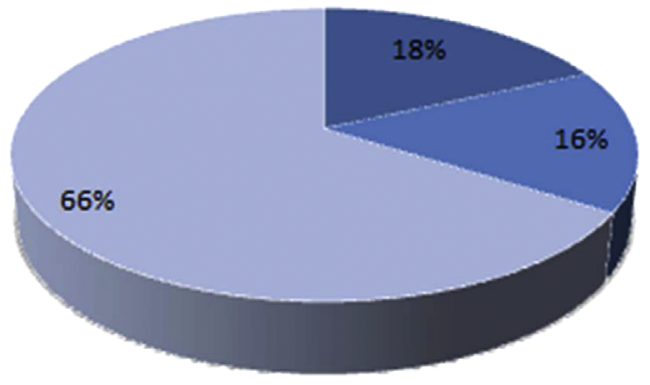

=Urban Floodings $=$ Flash Floods $=$ River Floods
B

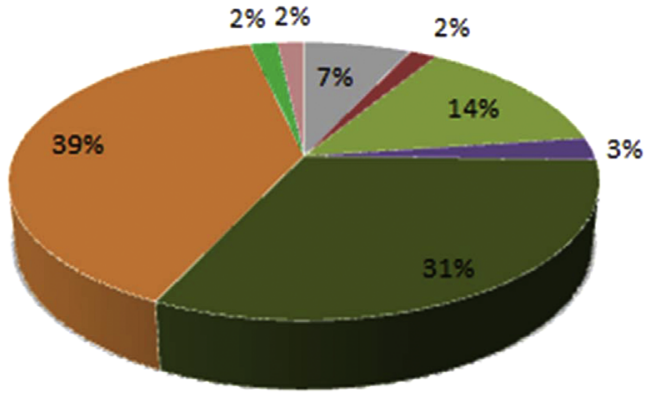

- Unidentified typology
- Mud flow

- Rotational Slide

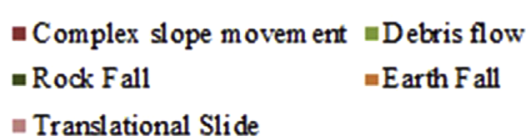

Fig. 3. Floods (A) and landslides (B) subtypes, in Northern Portugal in the period 1865-2010.

to rock falls and $14 \%$ to debris flows (Fig. 3), typologies already identified as the most frequent in the Variscan Massif of the north of Portugal $[7,8,39]$. Note also that most river floods, landslides and urban floodings take place mainly in winter (December, January and February), whereas flash floods are spread throughout the year. However, a significant percentage of flash floods (32\% of total) occur in the summer months (June, July and August), in association with high intensity rainfall episodes but of short duration.

In average, Northern Portugal records 4 hydrogeomorphological occurrences per year, that implies 4 deaths or injured or missing people and 127 displaced/ evacuated. The average flood mortality rate was 0.050 and the average landslide mortality rate was 0.032 .

\subsection{Temporal distribution of hydro-geomorphological occurrences in the analysed period}

The distribution of occurrences shows essentially great variability. By the technique of classification of data by natural breaks, it is possible to identify 3 time periods: until 1927, 1928-1970 and 1971-2010. However, if until 1927 the number of occurrences/year is generally less than 5 (except in 1909 and1910), after this date there a significant increase in this value, particularly in 1962, 1966, 1978, 1979, 1996 and 2001, with more than 20 occurrences/year (Fig. 4).

This first period represents $43 \%$ of the total time series and includes just $20.4 \%$ and $14 \%$ of flood and landslide occurrences. In the first time period the number mean of occurrences is 2 per year, but includes the year that registered the maximum number of flood occurrences, with 50 occurrences, although most of them relate to the same event: the river flood of the Douro River, considered as the largest throughout the entire 20th century. The second time period, from 1928 to 1970, represents 29\% of the total time series. A total of 241 flood occurrences (48.2\% of total flood occurrences) and 55 landslide occurrences (48.2\% of total landslide occurrences) were registered in this period. In the period 1928-1970, twenty-two years registered more than 5 occurrences, while between
1971 and 2010 there were only 10 years with more than 5 occurrences (Fig. 4). The last time period (1971-2010) corresponds to $27 \%$ of the total time series, 157 flood occurrences (31.4\% of total flood occurrences) and 43 landslide occurrences (37.7\% of total landslide occurrences) were registered. In the period between 1928 and 1970 (broken lines in Fig. 4), the average number of occurrences is 7/year, exceeding that of 1865-1927 (2 occurrences/year) and 1971-2010 (5 occurrences/year). As regards to landslides, in the entire series there were only 4 years with more than 5 occurrences per year. In relation to floods, however, there were more than 29 years with more than 5 occurrences. The years 1909, 1962, 1966, 1978, 1996 and 2001 stand out, with more than 20 occurrences/year.

In fact, the years with the highest number of occurrences show higher values of mean annual precipitation (MAP) (except 1909) indicating, as expected, the influence rainfall has on these processes (Fig. 5). The same applies to the RD and RDN (Fig. 6).

The result of the Mann-Kendall trend test suggests a small statistically significant upward trend, between 1865 and 2010, an increase of 0.17 occurrences/decade. If analysed by type of hydro-geomorphological disaster, we find that there is no increase trend for floods or landslides ( 0.000 per decade). The results of the trend test for the sub-periods calculated (until 1927, 1928-1970 and 19712010) do not show statistical significance (with a level of significance of $5 \%$ ).

Between 1908 and 2005, the Serra do Pilar meteorological station showed an increase in MAP of $6.03 \mathrm{~mm}$ per year, an increase in $\mathrm{RDN}$ (0.030 $\mathrm{mm}$ per year) and an increase of $\mathrm{RD}$ ( 0.231 days per year). However, the results for sub-periods do not show statistical significance.

\subsubsection{Geographical distribution}

From the total of 86 municipalities that are located in the study area, 77 (90\%) were affected by hydrogeomorphological occurrences between the years 1865 and 2010. Oporto, Vila Nova de Gaia and Peso da Régua have $36 \%$ of hydro-geomorphological occurrences, most of which are associated with river floods in the Douro basin. 


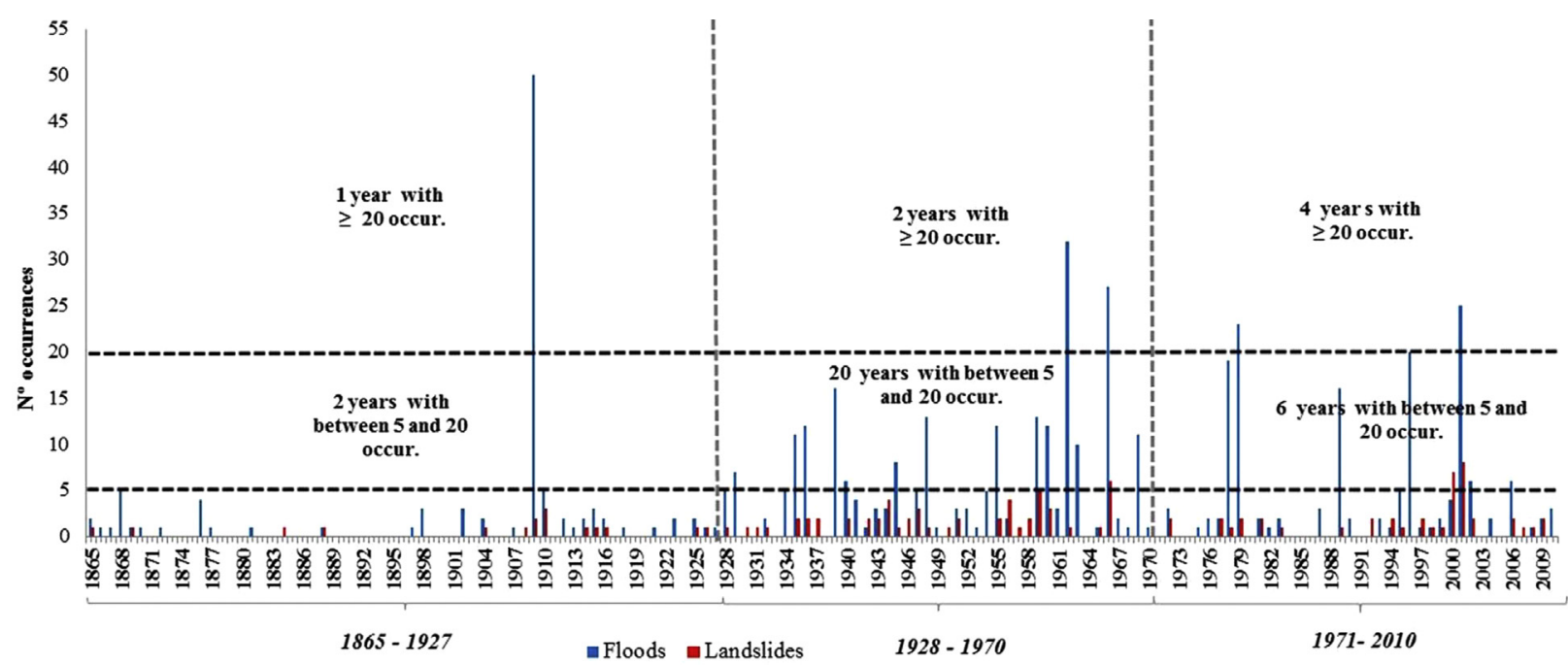

Fig. 4. Temporal distribution of floods and landslides occurrences in Northern Portugal in the period 1865-2010.

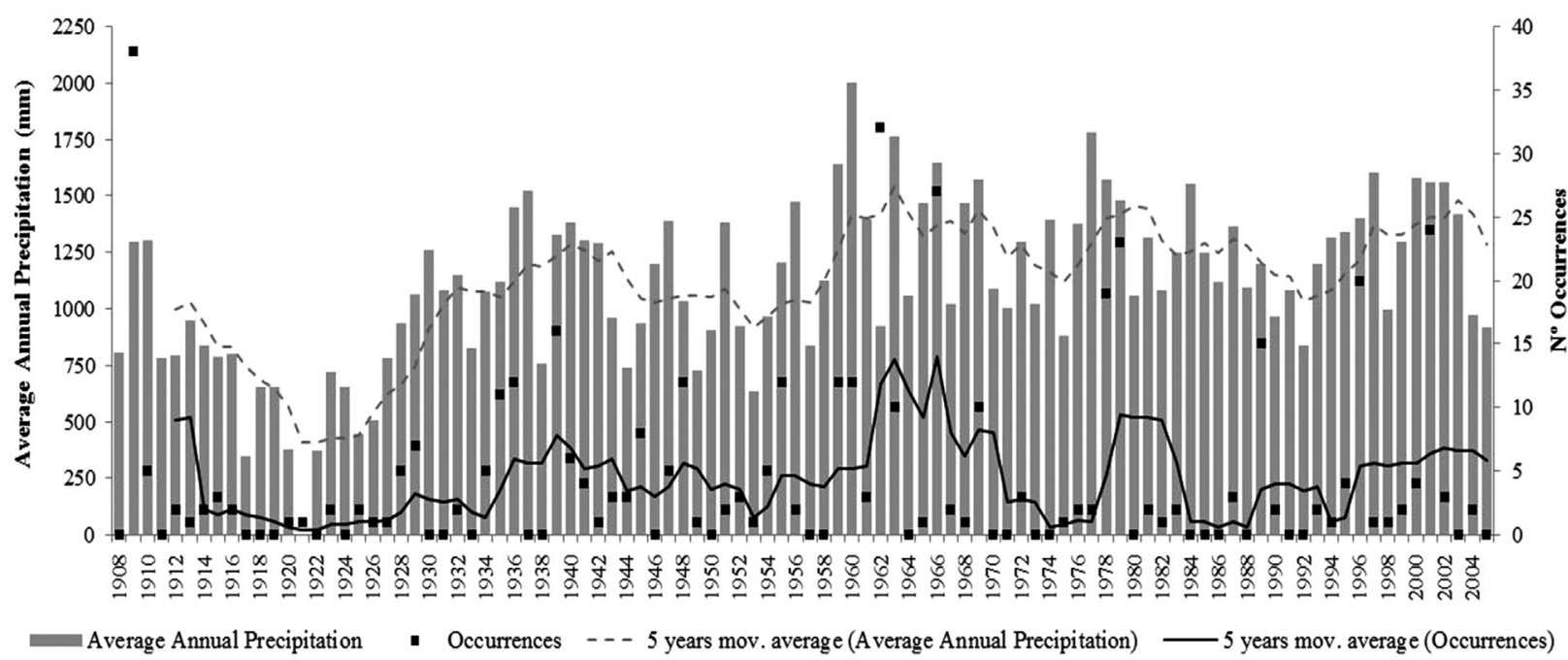

Fig. 5. Mean annual precipitation (MAP) (bars) in Serra do Pilar station, occurrences (dots) and moving averages for five years, for the period 1908-2005. Source: IPMA.

Table 3 summarizes the density and impacts of the floods that occurred in the six hydrographic sub-regions. The highest density is observed in the Ave and Leça hydrographic region $\left(0.05\right.$ cases per $\left.\mathrm{km}^{2}\right)$. The majority of floods occurrences (74\%) are located in areas where the mean annual precipitation (MAP) is higher than $1000 \mathrm{~mm}$ (Fig. 7).

The majority of death, injured and missing people due to floods occurred in the Douro region (68.6\% of total). In the same way Douro hydrographic region registered 93.9\% of total evacuees and displaced people, which results predominantly from river floods affecting the Oporto, Vila Nova de Gaia e Peso da Régua municipalities (Fig. 7). The municipalities with most floods occurrences also have the highest population density.

The majority of landslide occurrences (76\%) is located in areas where the MAP is higher than $1000 \mathrm{~mm}$, and 18\% of the landslides concentrate in areas with MAP between
600 and $1000 \mathrm{~mm}$ (Fig. 8). The density of landslide occurrences is the highest in the platform coastal (6.86 per $\mathrm{km}^{2}$ ) and along the Douro valley (5.4 per $\mathrm{km}^{2}$ ) (Table 4). The majority of dead, injured and missing people due to landslides occurred in the Douro Valley (39.2\% of total), coastal platform (25.3\%) and mountains (22.8\%). Evacuees and displaced people due to landslide occurrences are more numerous on the coastal platform $(75.7 \%$ of total) (Table 3).

Landslides are more frequent in the municipalities of Oporto, Vila Nova de Gaia, Arcos de Valdevez and in some areas of the Douro valley, covering part of the councils of Baião and Carrazeda de Ansiães. This concentration is related to the Douro railway line. In this case, it is important to consider the morpho-structural characteristics of the areas in question, particularly the aspects related to the presence of densely fractured steep rocky slopes (Fig. 8). 




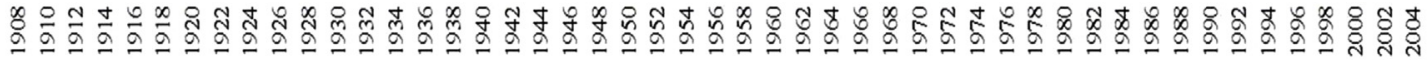

Rainy-day normal

---Number of rainy days

Fig. 6. Number of rainy days (RD) (line) and rainy-day normal (RDN=MAP/RD) (bars) in Serra do Pilar station for the period 1908-2005.

Table 3

Density and impacts of floods that occurred in the hydrographic regions.

\begin{tabular}{lrrlcc}
\hline $\begin{array}{l}\text { Hydrographic } \\
\text { region }\end{array}$ & $\begin{array}{l}\text { Area } \\
(\%)\end{array}$ & Occurrences & $\begin{array}{l}\text { Floods density } \\
\left(\# / \mathrm{km}^{2}\right)\end{array}$ & $\begin{array}{l}\text { Dead, injured and missing } \\
\text { people }(\%)\end{array}$ & $\begin{array}{l}\text { Displaced and homeless } \\
\text { people (\%) }\end{array}$ \\
\hline Ave and Leça & 7.9 & 84 & 0.05 & 12.8 & 4.3 \\
Cávado & 7.8 & 25 & 0.02 & 6.6 & 0.3 \\
Douro & 70.3 & 335 & 0.02 & 68.6 & 93.9 \\
Lima and Neiva & 6.9 & 32 & 0.02 & 7.2 & 0.6 \\
Minho & 4.4 & 14 & 0.01 & 3.8 & 0.2 \\
Vouga & 2.6 & 10 & 0.02 & 1 & 0.7 \\
Total & 100 & 499 & 0.02 & 100 & 100 \\
\hline
\end{tabular}

A

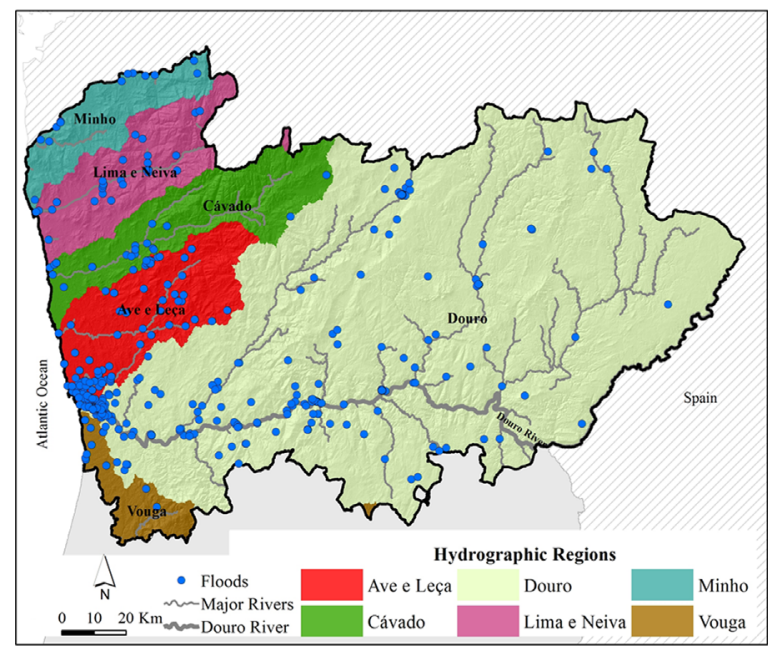

B

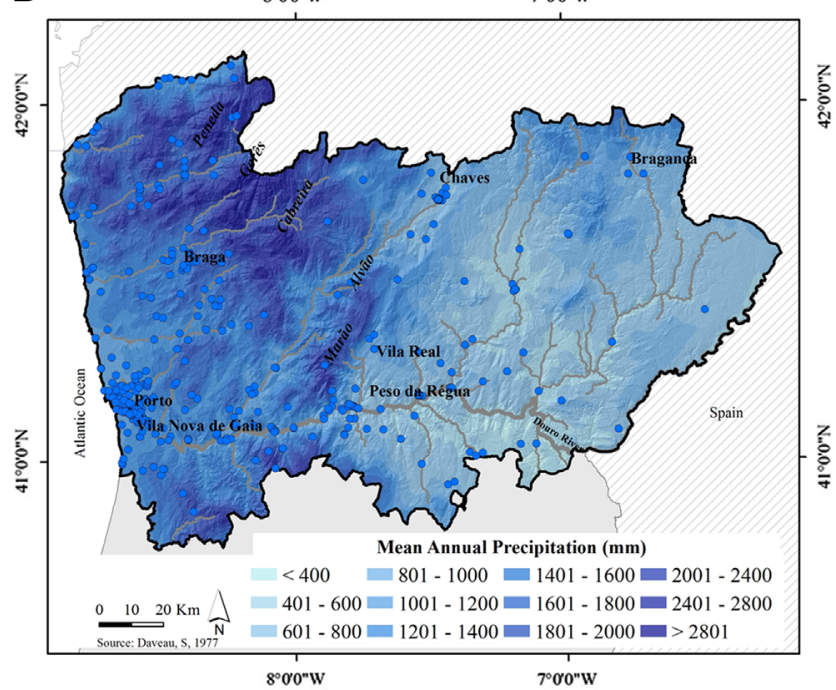

Fig. 7. Spatial distribution of flood occurrences in northern region in the period 1865-2010 and relationship with hydrographic regions (A) and mean annual precipitation (B).

The spatial pattern of hydro-geomorphological occurrences strongly reflects the people exposition. It however reveals the vulnerability of the exposed elements, alerting us to the problems that can result from the concentration of people and infrastructures. The natural conditions (e.g. rainfall regime, land use, relief, slope, lithological units) of floods and 
A

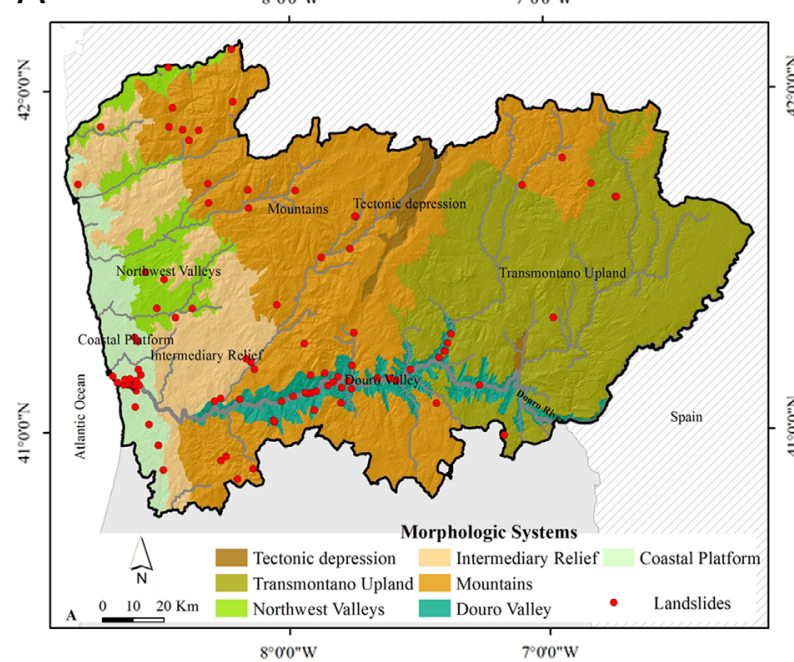

B



Fig. 8. Spatial distribution of landslides occurrences in northern region in the period 1865-2010 and relationship with morphologic systems (A) and mean annual precipitation (B).

Table 4

Density and impacts of landslides that occurred in the morphologic systems.

\begin{tabular}{|c|c|c|c|c|c|}
\hline Morphologic systems & Area (\%) & Occurrences & $\begin{array}{l}\text { Landslides density } \\
\left(\# / \mathrm{km}^{2}\right)\end{array}$ & Dead, injured and missing people (\%) & Evacuees and displaced people (\%) \\
\hline $\begin{array}{l}\text { Transmontano } \\
\text { Upland }\end{array}$ & 31.0 & 6 & 0.19 & 2.8 & 0.0 \\
\hline Coastal platform & 5.7 & 39 & 6.86 & 25.3 & 75.7 \\
\hline Intermediary relief & 11.2 & 7 & 0.62 & 5.6 & 0.1 \\
\hline Mountains & 39.5 & 28 & 0.71 & 22.8 & 17.4 \\
\hline Douro valley & 5.6 & 30 & 5.40 & 39.2 & 4.7 \\
\hline Northwest valleys & 5.5 & 4 & 0.73 & 4.3 & 2.0 \\
\hline Tectonic depression & 1.5 & 0 & 0.00 & 0.0 & 0.0 \\
\hline Total & 100 & 114 & 1.14 & 100 & 100 \\
\hline
\end{tabular}

landslides are also important as to the spatial distribution of these processes. An example of this situation is illustrated in the Arcos de Valdevez area, that despite a low population density (51 inhabitants/sq km), 14 occurrences have been registered during the period under analysis, causing 13 deaths, 2 missing persons, 13 injured, 24 evacuated and 19 displaced.

Another important aspect must be pointed out, when we analyse the damages by administrative unit and type of process: we can see that in $67 \%$ of the municipalities, at least one person died, was injured or disappeared during a flood, decreasing this number to $41 \%$ in the case of those affected by landslides with similar consequences.

The municipalities with most people affected by floods are Oporto, Vila Nova de Gaia, Chaves and Peso da Régua (Fig. 9). The municipality of Oporto also features more people affected as result of landslides, along with the municipalities of Peso da Régua, Baião and Cabeceiras de Basto (Fig. 9). In the case of Cabeceiras de Basto, a single landslide caused 15 deaths and 14 injured on 27 December, 1981.

\section{Discussion and conclusions}

A broad knowledge on past events is therefore essential for risk management, spatial planning and emergency planning. This paper presents the DISASTER GDB, a database on landslides and floods that have occurred in Northern Portugal between 1865 and 2010. Based on a systematic collection in national, regional and local newspapers, this database includes hydro-geomorphological occurrences that resulted in dead, injured, missing, evacuees or displaced persons, regardless of the economic value of damages. The newspapers highlight largemagnitude events that occurred in urban areas or that caused damage for people or structures. The events of low magnitude or those that do not cause extensive damage may not appear in the newspapers. However, significant work was involved in checking and validating all the information and it is assumed that occurrences are important enough to be reported in the regional and national newspapers.

In total, we identified 613 occurrences in Northern Portugal, $18 \%$ of which are landslides and $82 \%$ are floods. These occurrences were responsible for 198 dead, 58 injured, 34 disappeared, 1804 evacuated and 15,918 displaced. Three time periods were established: until 1927, 1928-1970 and 19712010. The first period (1865-1927) was characterized by the low number of occurrences; 2 occurrences per year on mean. The second period (1928-1970) is marked by the highest 
A

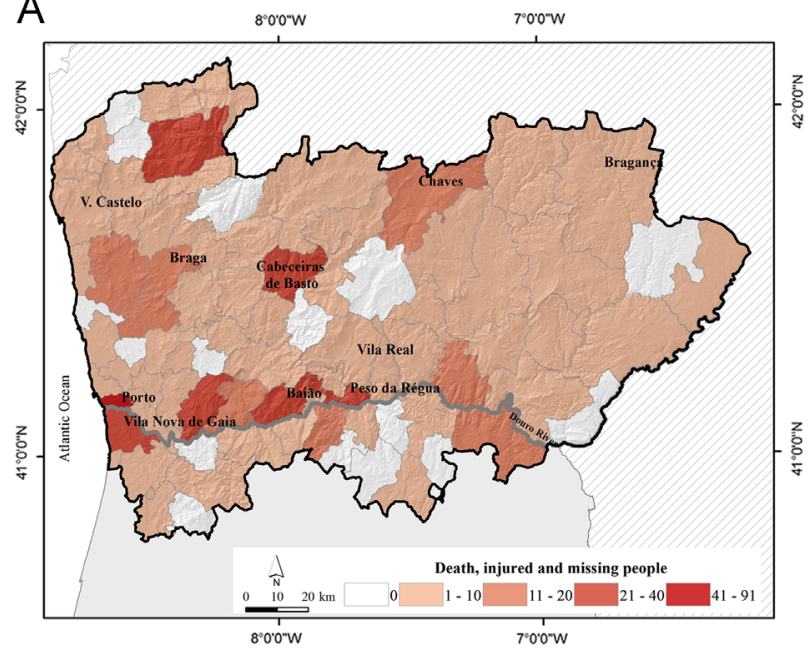

B



Fig. 9. (A) Dead, injured or missing people, by municipality and (B) displaced or evacuated people, in the Northern Portugal, the 1865-2010.

number of occurrences; 7 per year on mean. Finally, in the third period (1971-2010) the annual mean number is 5 occurrences. For the first period, we admit that this database is certainly incomplete, because the newspapers cover mostly the urban areas (such as Oporto, Vila Nova de Gaia and Matosinhos) or places whose accessibility depends largely on specific transport networks, including the railway line between Oporto and Barca d'Alva (Douro Line). The decrease of occurrences in the third period may be related to decreased rainfall. A work on temporal variability of extreme precipitation indices in Northern Portugal in the period of 1950-2000 [24], shows a decrease in extreme precipitation indices during annual scale, spring, winter and summer. The decreasing trends in winter and early spring in this period are possibly associated with the predominance of the positive phase of the NAO index between the 1960's and 1990's [40,41].

The result of the Mann-Kendall trend test suggests a small statistically significant upward trend (an increase 0.17 occurrences/decade) but if we analyse by type of hydro-geomorphological disaster, there is no increase trend for floods or landslides ( 0.000 per decade). The precipitation indices presented (MAP, RD and RDN) also exhibit increase trends. However, there were only calculated for one station, between 1908 and 2005, which effectively does not represent the reality of the entire Northern Region. Santos and Fragoso [24], previously showed a scarce spatial consistency on trends observed in various indices of precipitation extremes in the region. According Llasat et al. [42], in addition to the precipitation, other causes must be investigated, such as land-use and land-cover changes, changes in runoff, and the growing occupation of flood areas.

The spatial pattern of hydro-geomorphological occurrences reflects the people localization and infrastructures, but also the most affected areas present a natural predisposing condition which promotes the occurrence of floods or landslides. The urban centres and the areas along major rivers are the place where most of the occurrences concentrate. We must highlight the great urban centre formed by the municipalities of Oporto and Vila Nova de Gaia, since they record $30 \%$ of the hydro-geomorphological occurrences and hold the largest number of residents.

The maximum density of flood occurrences is observed in the Oporto, Vila Nova de Gaia as well as along the Douro valley and river. The maximum density of landslides occurs in Oporto, Vila Nova de Gaia, Arcos de Valdevez and Baião municipalities and along the Douro valley. In the first two municipalities, morphology is conducive only of the occurrence of landslides in small areas of the councils, and even then the processes cause damages, while in Arcos de Valdevez and Baião a significant part of the area is prone to the occurrence of landslides.

Floods were responsible for most displacements (96\%), evacuees (92\%), missing (89\%) and dead (60\%), while 76\% of the injuries were caused by landslides. In Northern Portugal the mortality rate associated with floods was 0.050 and the landslide was 0.032 .

The present study is an important contribution to knowledge the historical hydro-geomorphological occurrences in Northern Portugal and for civil protection and spatial planning authorities, since it identifies the critical points for emergency management. Forthcoming studies aim at investigating the relationship between hydrogeomorphological occurrences and land-use changes or the growing occupation of flood areas.

\section{Acknowledgements}

This work was supported by the Portuguese Foundation for Science and Technology (FCT) through the Project DISASTER - GIS database on hydro-geomorphologic disasters in Portugal: a tool for environmental management and emergency planning (PTDC/CS-GEO/103231/2008).

\section{References}

[1] Daveau S. Répartition et rytme des précipitations au Portugal. Editorial Império ed, ed. M.d.C.d.E. Geográficos. vol. 3. Lisboa; 1977.p. 189. 
[2] UNISDR, Factsheet: global 2012 disasters in numbers. United Nations office for disaster risk reduction (UNISDR); 2013.

[3] Hilker N, Badoux A, Hegg C. The Swiss flood and landslide damage database 1972-2007. Nat Hazards Earth Syst Sci 2009;9:913-25.

[4] Fragoso M, Trigo RM, Pinto JG, Lopes S, Lopes A, Ulbrich S, et al. The 20 February 2010 Madeira flash-floods: synoptic analysis and extreme rainfall assessment. Nat Hazards Earth Syst Sci 2012;12: 715-30.

[5] EM-DAT. CRED EM-SAT: the OFDA/CRED international disaster database, www.emdat.be; 2013, [cited 25.06.13].

[6] Barnolas M, Llasat MC. A flood geodatabase and its climatological applications: the case of Catalonia for the last century. Nat Hazards Earth Syst Sci 2007;7(2):271-81.

[7] Pereira S. Perigosidade a movimentos de vertente na região Norte de Portugal. Porto: Faculdade de Letras da Universidade do Porto; 373.

[8] Soares L. A Importância das Formações Superficiais no Âmbito dos Processos de Erosão Hídrica e Movimento de Vertente no NW de Portugal. Porto: Faculdade de Letras da Universidade do Porto; 887.

[9] Evans, S.G., The record of disastrous landslides and geotechnical failures in Canada 1840-1999; implications for risk management. In: Proceedings of the 53rd Canadian geotechnical conference workshop on geotechnique and natural hazards, Montreal; 2000.

[10] Devoli G, Morales A, Høeg K. Historical landslides in Nicaragua collection and analysis of data. Landslides 2007;4(1):5-18.

[11] Guzzetti F, Tonelli G. Information system on hydrological and geomorphological catastrophes in Italy (SICI): a tool for managing landslide and flood hazards. Nat Hazards Earth Syst Sci 2004;4: 213-32.

[12] EM-DAT. The OFDA/CRED international disaster database, www. emdat.be; 2014 [accessed 07.14].

[13] Velásquez, C.A. Cardona, O.D. Carreño, M.L. Barbat, A.H. Retrospective assessment of risk from natural hazards. Int J Disaster Risk Reduction, http://dx.doi.org/10.1016/j.ijdrr.2014.05.005.

[14] Black A, Law F. Development and utilization of a national web-based chronology of hydrological events. Hydrolog Sci J 2004;49:237-46.

[15] Blong R. Issues in risk science, natural hazards risk assessment: an australian perspective. Benfield Hazard Research Centre; London; 27.

[16] Cutter SL, Emrich C. Are natural hazards and disaster losses in the U. S. increasing? Eos Trans Am Geophys Union 2005;86(41):381-9.

[17] Tudor, C. EPC electronic disaster database and its characteristics. In: Proceedings of the Project Report 97-1, Emergency Preparedness Canada: Canadá; 1997. p. 32.

[18] Gaspar JL, Goulart C, Queiroz G, Silveira D, Gomes A. Dynamic structure and data sets of a GIS database for geological riskanalysis in the Azores volcanic islands. Nat Hazards Earth Syst Sci 2004;4: 233-42.

[19] Llasat MC, Llasat-Botija M, López L. A press database on natural risks and its application in the study of floods in Northeastern Spain. Nat Hazards Earth Syst Sci 2009;9:2049-61.

[20] Forte F, Pennetta L, Strobl RO. Historic records and GIS applications for flood risk analysis in the Salento peninsula (Southern Italy). Nat Hazards Earth Syst Sci 2005;5:833-44.

[21] Petrucci O, Versace P. ASICal: a database of landslides and floods occurred in Calabria (Italy). In: R. Gaudio, editor. Proceedings of the 1st Italian-Russian workshop on new trends in hydrology. Cosenza, Rende (CS), Italy: Bios; 2004, CNR-GNDCI no. 2823. pp. 49-55.

[22] Naulet R, Lang M, Coeur D, Gigon C. Collaboration between historians and hydrologists on the Ardeche river (France). In: Glade T,
Albini F, Francés F, editors. The use of historical data in natura hazard assessments. Netherlands: Springer, Vol. 17; 2001. p. 113-29. [23] Daveau, S. Portugal Geográfico. Lisboa; 2000.

[24] Santos M, Fragoso M. Precipitation variability in Northern Portugal: data homogeneity assessment and trends in extreme precipitation indices. Atmos Res 2013;131:34-45.

[25] Ferreira DB. O Ambiente Climático. In: Medeiros CA, editor. Geografia de Portugal Vol. I - Ambiente Físico. Lisboa: Círculo de Leitores; 2005. p. 495.

[26] Zêzere JL, Pereira S, Tavares AO, Bateira C, Trigo RM, Quaresma I. DISASTER: a GIS database on hydro-geomorphologic disasters in Portugal. Nat Hazards 2014;72(2):503-32.

[27] Guzzetti F, Stark C, Salvati P. Evaluation of flood and landslide risk to the population of Italy. Environ Manag 2005;36(1):15-36.

[28] Quaresma I. Inventariação e análise de eventos hidro-geomorfológicos com carácter danoso em Portugal Continental, in Departamento de Geografia. Lisboa: Universidade de Lisboa; 110.

[29] Salvati P, Bianchi C, Rossi M, Guzzetti F. Societal landslide and flood risk in Italy. Nat Hazards Earth Syst Sci 2010;10(3):465-83.

[30] Jenks GF. The data model concept in statistical mapping. Int Yearb Cartogr 1967;7:186-90.

[31] Piacentini D, Troiani F, Soldati M, Notarnicola C, Savelli D, Schneiderbauer S, et al. Statistical analysis for assessing shallow-landslide susceptibility in South Tyrol (south-eastern Alps, Italy). Geomorphology 2012;151-152(0):196-206.

[32] Joseph M, Wang F, Wang L. GIS-based assessment of urban environmental quality in Port-au-Prince. Haiti Habitat Int 2014;41(0): $33-40$.

[33] Martinez-Martinez E, Nejadhashemi AP, Woznicki SA, Love BJ Modeling the hydrological significance of wetland restoration scenarios. J Environ Manag 2014;133(0):121-34.

[34] Kendall S. Time series. New York: Oxford Univ. Press; 1976.

[35] Salmi T, Määttä A, Anttila P, Guoho-Airola T, Amunell T. Detecting trends of annual values of atmospheric pollutants by the MannKendall test and Sen's slope estimates - the excel template application MAKESENS. Vol. publications on air quality. Helsinki: Finnish Meteorological Institute; 2002.

[36] Gallego MC, Trigo RM, Vaquero JM, Brunet M, García JA, Sigró J, et al. Trends in frequency indices of daily precipitation over the Iberian Peninsula during the last century. J Geophys Res 2011;116:D02109.

[37] Theil H. A rank-invariant method of linear and polynomial regression analysis. I, II, III. Nederl Akad Wetensch Proc 1950;53 386-392, 521-525, 1397-1412.

[38] Sen PK. Estimates of the regression coefficient based on Kendall's tau. J Am Stat Assoc 1968;63:1379-89.

[39] Bateira C, Soares L. Movimentos em massa no norte de Portugal. Factores da sua ocorrência. Territorium - Revista de Geografia Física aplicada ao Ordenamento do Território 1997;4:63-77.

[40] Paredes D, Trigo RM, Garcia-Herrera R, Trigo IF. Understanding precipitation changes in Iberia in early spring: weather typing and storm-tracking approaches. J Hydrometeorol 2006;7(1):101-13.

[41] Trigo RM. In: Soares A, Pereira MJ, Dimitrakopoulos R, editors. Quantifying the impact of the North Atlantic oscillation on Western Iberia, in geoENV VI - geostatistics for environmental applications. Berlin: Springer; 2008, p. 235-46.

[42] Llasat MC, Marcos R, Llasat-Botiji M, Gilabert J, Turco M, QuintanaSeguí P. Flash flood evolution in North-Western Mediterranean. Atmos Res 2014;149(0):230-43. 